\title{
FUNGI ISOLATED FROM SOIL BEFORE THE SEEDING AND AFTER HARVEST OF PEA (PISUM SATIVUM L.) AFTER APPLICATION OF BIO-CONTROL PRODUCT EM 1 TM
}

\author{
Adam Okorski ${ }^{1}$, Barbara Majchrzak² \\ ${ }^{1}$ Department of Diagnostics and Plant Pathophysiology, ul. Plac Łódzki 6, 10727 Olsztyn, Poland \\ e mail adam.okorski@uwm.edu.pl \\ ${ }^{2}$ Department of Phytopathology and Entomology UWM ul. Prawocheńskiego 17, 10722 Olsztyn, Poland
}

Received: 20.02 .2007

\begin{abstract}
Su m m a r y
A field experiment was performed during the years 2003 2005. An influence of EM (Effective Microorganisms) on the composition and number of fungi isolated from soil was found in the experiment. A total of 18111 fungal cultures were isolated from the roots of pea at flowering stage. The highest amount and the lowest diversity of fungi were obtained from rhizosphere of pea treated with pesticides (3257 colonies). The greatest diversi ty of fungi was found in the case of rhizosphere and rhizoplane, where EM was used in soil with the supplement of pesticides. The greatest amount and diversity of fungi were found from the plant roots of the control object. During the flowering stage, the fungi most frequently isolated from soil belonged to the genus Penicillium (40.78\% of all isolates) and Fusarium (33.37\% of all isolates).
\end{abstract}

Key words: pea, rhizosphere, effective microorganisms

\section{INTRODUCTION}

The zone that surrounds the roots of plants and germinating seeds, inhabited by populations of soil microorganisms characterized by a great abundance of species, is referred to as the rhizosphere (Morgan et al. 2005). The populations of rhizosphere microorganisms contribute to the stability and productivity of both agricultural systems and those functioning under natural conditions. The efficiency of the above systems can be improved by increasing the microbial diversity of soil ecosystems, positively affecting the overall health and productivity of crops. The effectiveness of biological control in plant protection and microbial agents used as biofertilizers can be enhanced by combining various specific antagonists (Davelos et al. 2004). Effective Microorganisms (EM) is a microbial inoculant compri- sed of 70 species belonging to five groups, including lactic acid bacteria, photosynthetic bacteria, actinomycetes, yeast-like fungi and mycelial fungi (Valarini et al. 2003). The application of EM has a beneficial effect on soil structure and quality (Hussain et al. 1999; $\mathrm{K}$ haliq et al. 2006). According to Daly and Stewart (1999), the use of effective microorganisms is not an alternative to traditional agricultural practices aimed at increasing crop productivity, but rather a complementary option. Ol an y a and Lark in (2006) demonstrated that EM was less effective than chemicals in disease control. In Poland the microbial preparation $\mathrm{EM}^{\mathrm{TM}}$ is registered as a soil improver to be used in ecological agriculture (Certificate of Conformity No. Z/13/PR-20001/03/BP). The preparation has been approved as safe for the environment and to human health (Certificate issued by the National Institute of Hygiene No. PZH/HT-1448/2002).

The aim of this study was to determine the impact of effective microorganisms (EM), applied to soil, as seed dressing or as foliar spray, on quantitative and qualitative changes in fungal populations colonizing the soil environment of pea grown in a conventional tillage system.

\section{MATERIALS AND METHODS}

The study was conducted during the years 2003 - 2005 at the Experimental Station in Tomaszkowo near Olsztyn, on plots of the Department of Phytopathology and Entomology, University of Warmia and Mazury in Olsztyn. An exact field experiment was established on brown soil developed from silt (2003) of quality class IVa and good rye-potato complex, medium silty loam of quality class IVa and rye-potato complex (2004), and light loam of quality class IIIb and complex 4 (2005). 
Winter triticale was grown as forecrop in 2003 and 2005, and spring barley in 2004. The experiment was laid out in a randomized split-plot design in four replications. The plot surface area was $16 \mathrm{~m}^{2}$. The experimental factor was the method of EM application:

1. control treatment (no effective microorganisms or crop protection chemicals),

2. chemical control ( $\mathrm{T}$ seed dressing, fungicide Rovral Flo 250 SC, insecticide Owadofos 540 EC, herbicide Basagran 480 SL),

3. soil application of EM combined with chemical control,

4. seed dressing with EM combined with chemical control, cal control,

5. plant spraying with EM combined with chemi-

6. soil application of EM combined with seed dressing and plant spraying with EM.

Prior to soil application, the biopreparation EM was proliferated as recommended by the manufacturer (Greenland). A $0.1 \%$ solution of effective microorganisms (1 1 water: $1 \mathrm{~cm}^{3}$ EM: $1 \mathrm{~g}$ saccharose) was stored in a dark place at about $20^{\circ} \mathrm{C}$ for 14 days. Seeds were dressed with effective microorganisms wet, for $30 \mathrm{~min}$., using a previously prepared $0.2 \%$ solution of EM (applied at a dose of $2001 \cdot \mathrm{ha}^{-1}$ ). Prior to pea sowing, the fungal populations inhabiting the soil were analyzed by a plate method modified by Mań k a (1974). The fungal communities were isolated from the rhizosphere, rhizoplane and the roots of pea plants using the washings method developed by Mańka (1974). A microbiological analysis was performed at the full blooming stage.

\section{RESULTS}

Prior to pea sowing, 196 fungal cultures representing 40 species and non-spore-forming cultures were isolated from the soil (Tab. 1). Among the isolated fungi, the dominant group comprised potential antagonists of plant pathogens $(48 \%)$, including members of the genera Penicillium (21\% of all isolates), Gliocladium (13\%) and Mucorales (9\%). Potentially pathogenic fungi, i.e. such species as Cylindrocarpon destructans, Botrytis cinerea, Rhizoctonia solani and Fusarium sp., accounted for $14 \%$ of all isolates. Half of them ( $7 \%$ of all isolates) were members of the genus Fusarium. The species $F$. dimerum, $F$. oxysporum and $F$. solani were isolated most frequently.

11328 cultures of mycelial fungi (Tab. 2) were isolated from the rhizosphere of pea at the flowering stage. The most numerous fungal communities, characterized by the lowest species diversity, were isolated from chemically protected plots (3 257 fungal cultures belonging to 36 species). The highest species diversity (53 species) was observed in the plots where soil application of EM was combined with chemical control.
The control plots were colonized by fungal populations of the smallest size. The rhizosphere was dominated by antagonists ( $63 \%$ of all isolates), of which $41 \%$ were members of the genus Penicillium. Pathogenic fungi constituted $33 \%$ of all isolates in this zone. The dominant genus was Fusarium (32\%), including F. oxysporum $-18.75 \%$ and $F$. equiseti $-10.07 \%$. Pathogenic fungi were most common $(50.16 \%)$ in the experimental variant in which seeds were dressed with effective microorganisms. Antagonists were isolated most seldom in this variant $(44.96 \%)$. They dominated in the soil application of EM $x$ chemical control treatment $(72.86 \%)$.

5601 cultures of mycelial fungi (Tab. 2) were isolated from the rhizoplane of pea at the flowering stage. The largest communities were isolated from the experimental variant in which EM was applied without chemical control (1834 isolates). The highest species diversity (49 species) was observed in the case of soil application of effective microorganisms combined with chemical control. The fewest isolates (527) were obtained from the control treatment, and the lowest species diversity (38 species) was recorded in the chemically protected treatment. Antagonistic fungi dominated in the rhizoplane of pea (69.1\%). Members of the genus Penicillium were isolated most frequently (45.3\%). Pathogenic fungi accounted for $28.8 \%$ of all isolates in this zone, with a distinct domination of Fusarium oxysporum (20.42\%). The largest communities of potentially pathogenic fungi $(51.54 \%)$ were isolated from the plots where seeds were dressed with EM. Almost half of them (44.18\%) were antagonistic fungi. Pea plants in the control treatment were also colonized by numerous fungal pathogens (42.69\%), of which $54.27 \%$ were antagonists. Antagonistic fungi dominated in the experimental variants in which soil or foliar application of EM was combined with chemical control (76.77\% and $76.15 \%$, respectively).

Fewer mycelial fungi were isolated from the roots of pea plants - 1183 colonies (Tab. 2). The largest and characterized by the greatest species abundance communities of mycelial fungi were isolated from the control treatment (246 isolates representing 36 species). The fewest fungal colonies (155 cultures) were obtained from the variant where foliar application of EM was combined with chemical control. The lowest species diversity (28 species) was observed in the plots protected with effective microorganisms without chemical control. The root-colonizing populations were dominated by pathogenic fungi (62\%) of all isolates), including the species Fusarium oxysporum (41.59\%), Phoma madicaginis var. pinodella $(6.85 \%)$ and Fusarium solani $(5.83 \%)$. Antagonists constituted $32 \%$ of all fungi isolated from the roots of pea plants. The largest population of potentially pathogenic fungi was recorded in the case of soil application of effective microorganisms $(75.32 \%)$. The percentage of antagonistic fungi was the lowest in this treatment $(18.35 \%)$. The fewest 

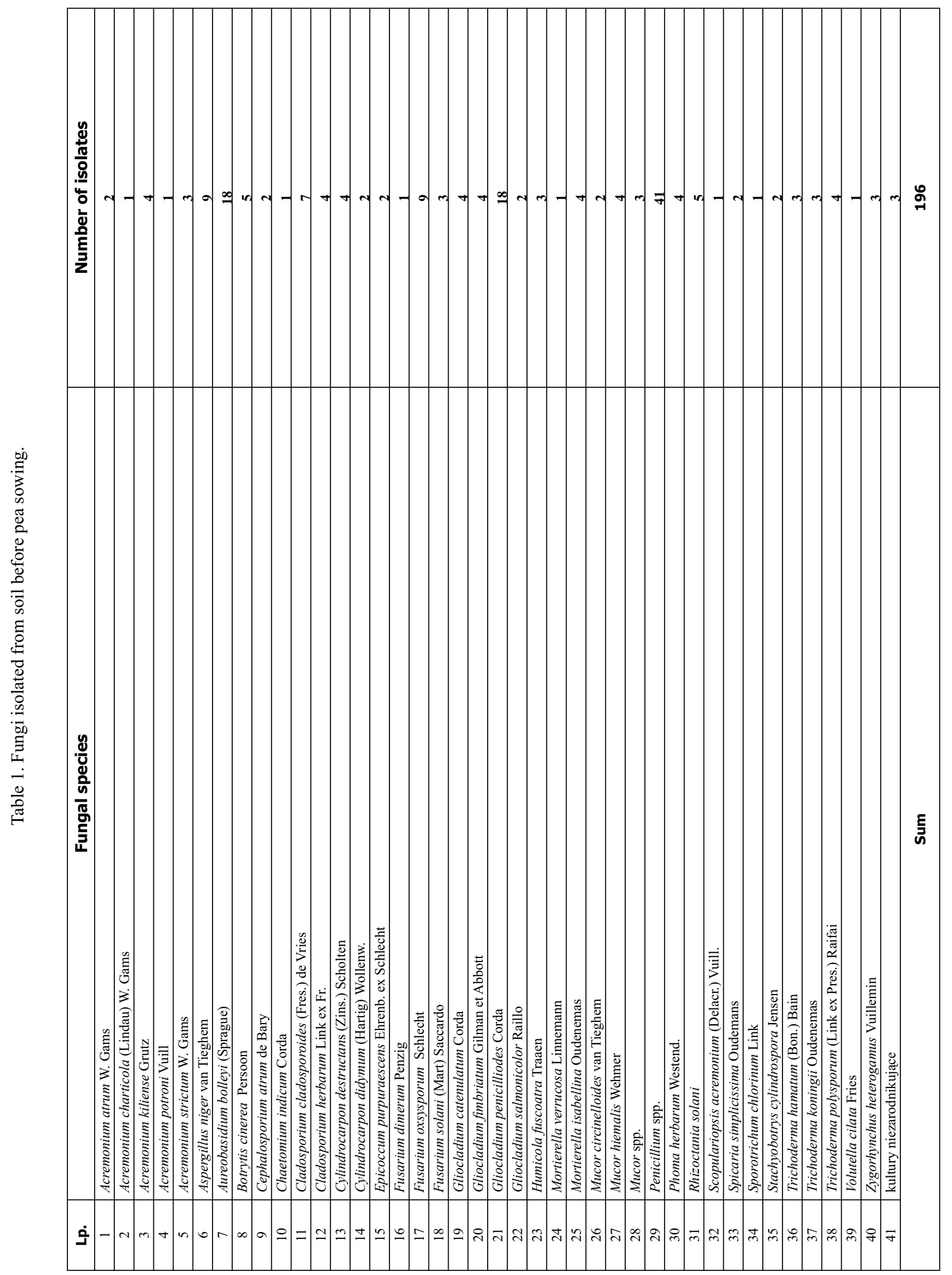


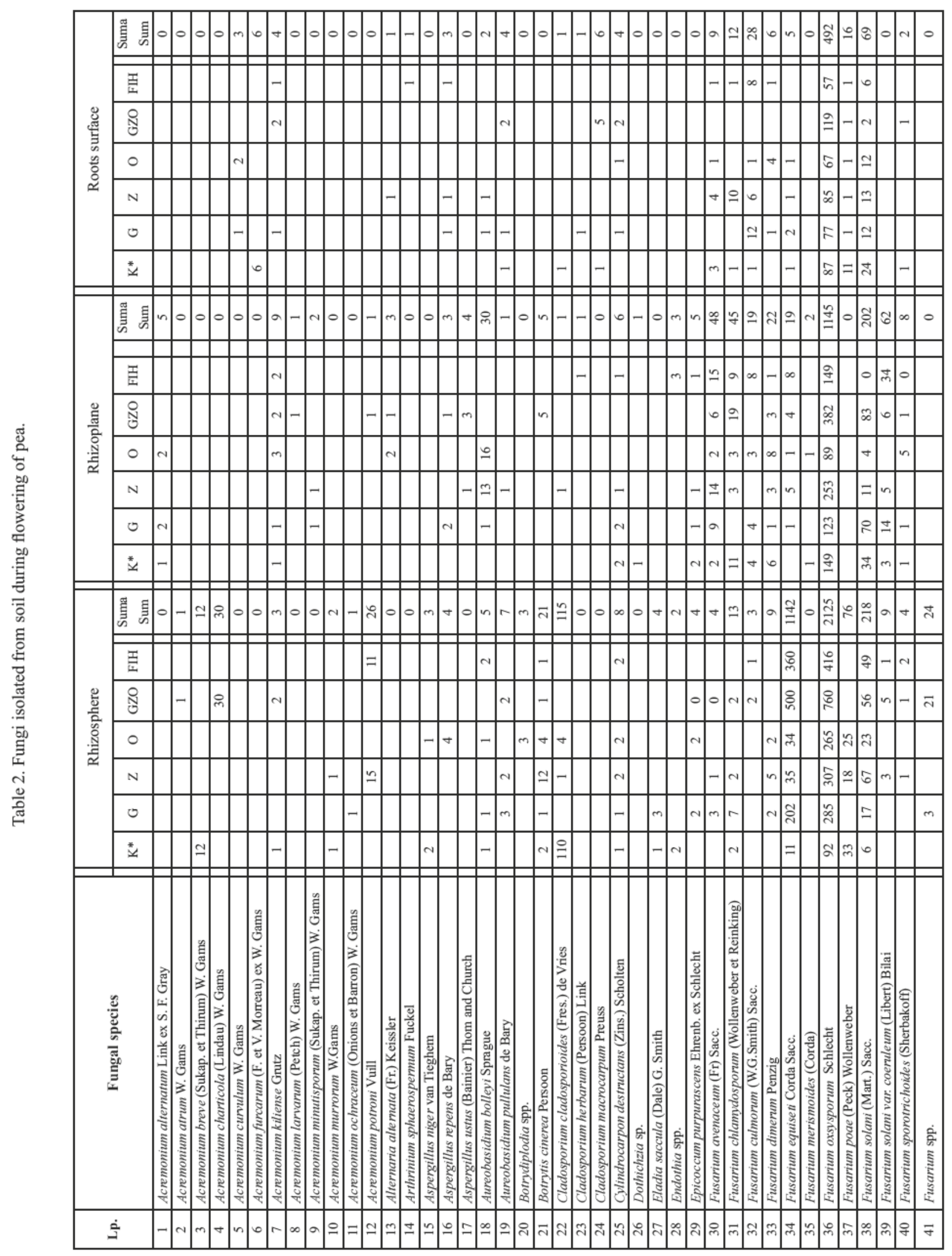




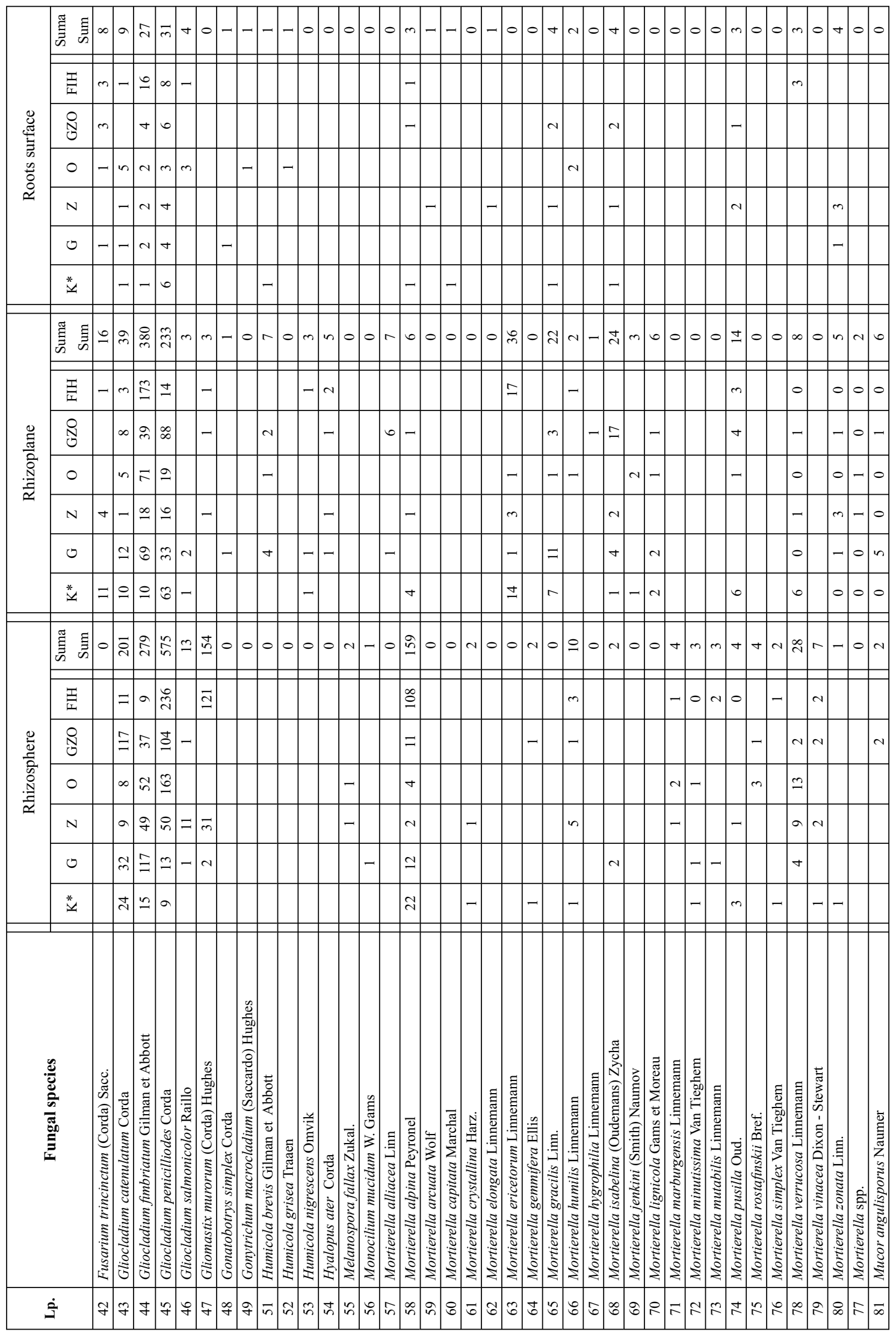




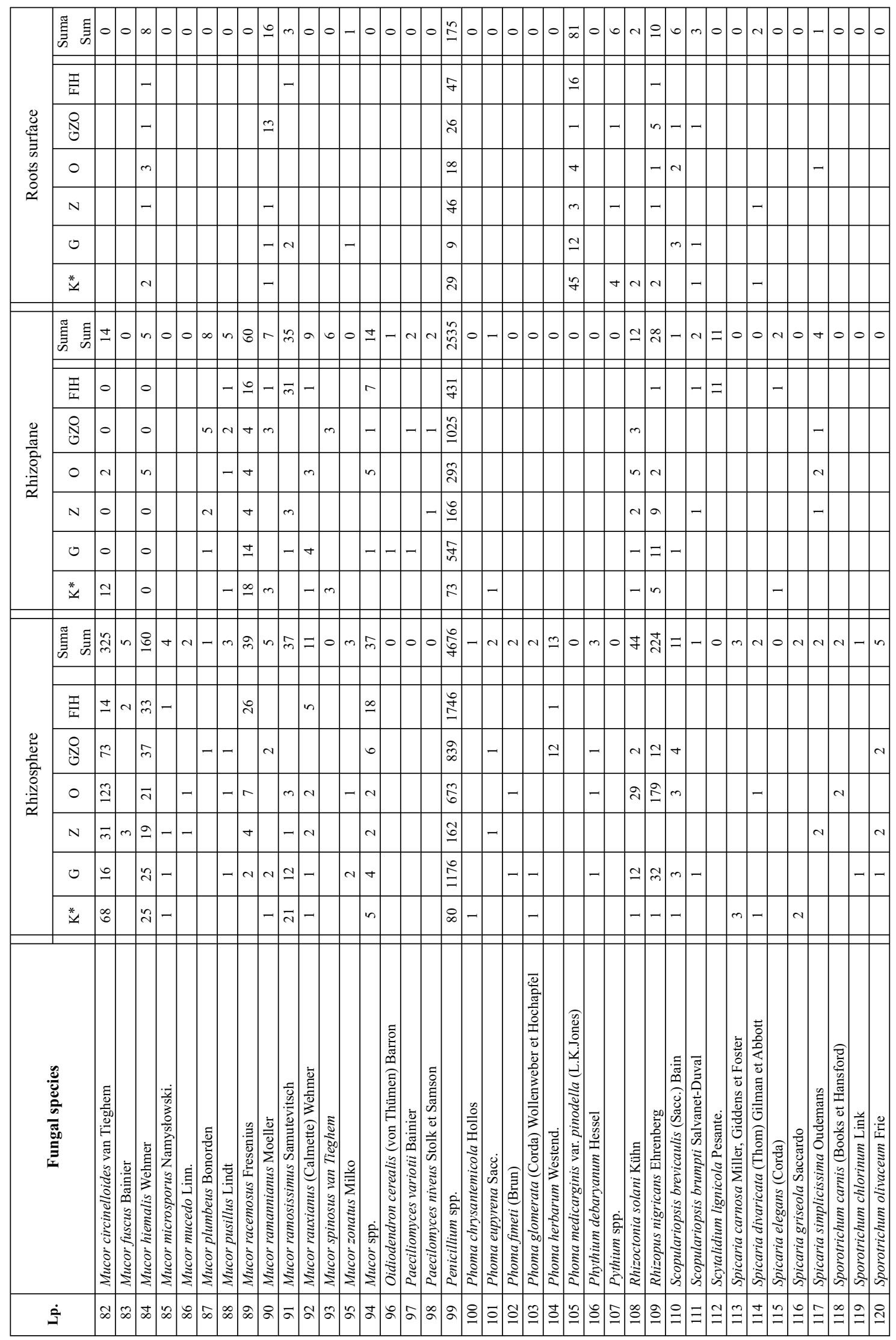




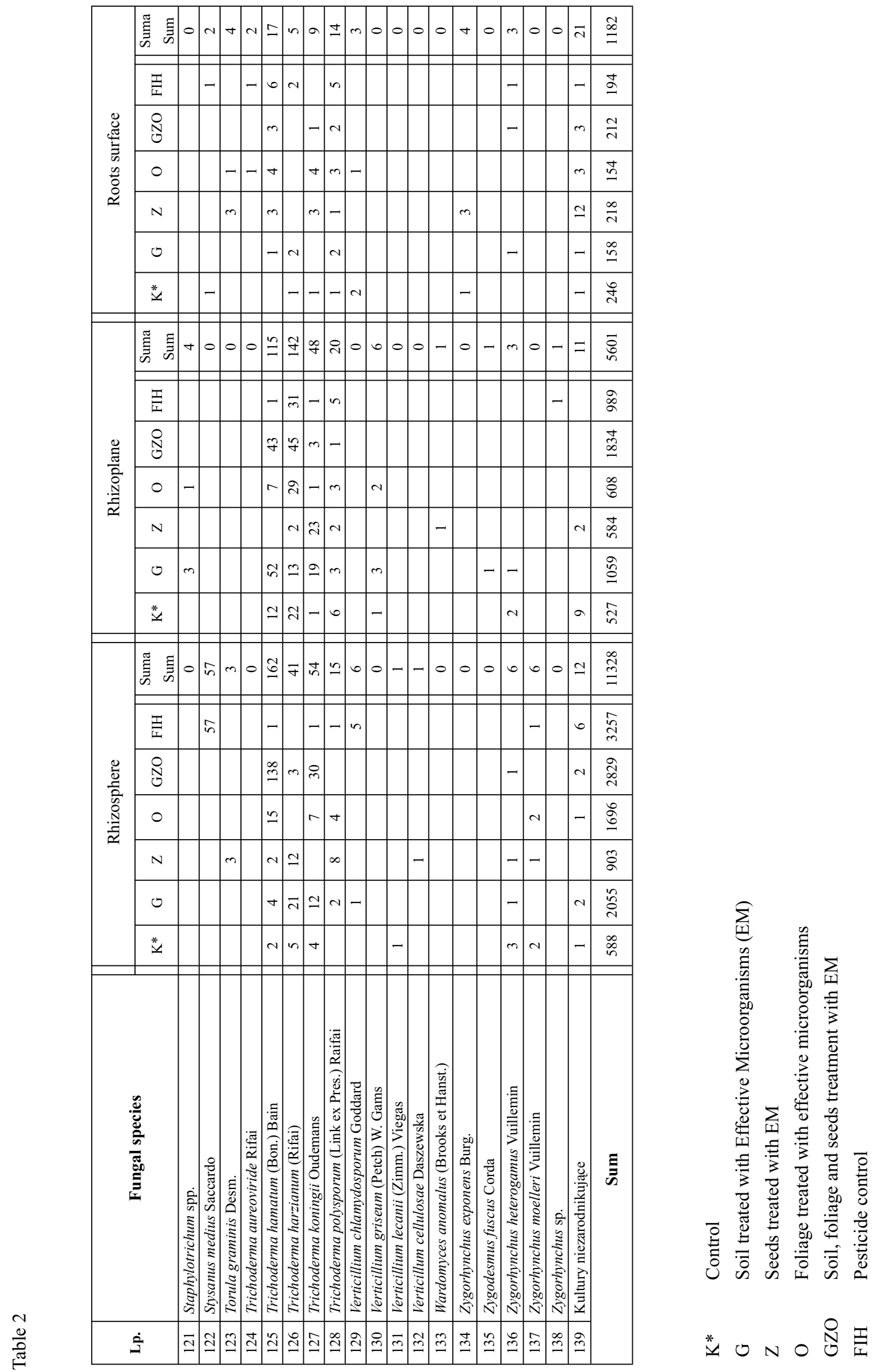


pathogenic fungi $(48.45 \%)$ were isolated from the roots of chemically-protected pea plants, with a high contribution of antagonists (49.48\%).

\section{DISCUSSION}

Chemical control in crop protection contributes to the selection of soil fungi, often followed by the disappearance of entire groups of soil microbes that perform an important role in ecosystems (Różańs ki 1992). Plant roots secrete a variety of organic substances, including amino acids, carbohydrates and organic acids, which affect the microorganisms colonizing the root system. These compounds increase the size of microbial populations and enhance their microbiological activity (B oer et al. 2005). In the present study, fungal species considered pathogenic - Cylindrocarpon destructans, Botrytis cinerea and Rhizoctonia solani, as well as Fusarium sp. and Pythium sp. (S eifert et al. 2003, Fournier et al. 2003, Oy arzun et al. 1998), were most frequently isolated from the roots of pea plants and their proportion decreased along with a growing distance from the root system. Fusarium oxysporum, responsible for Fusarium wilt of pea, was the most often isolated species. Fravel et al. (2003) reported that this fungus occurs in a non-pathogenic form, so it may be used for biological disease control. Members of the genus Penicillium can be found in all types of soil in considerable numbers. According to Seredyn (1988), these are antagonists of pathogenic fungi. Our study also showed that fungi of this genus are common in the soil environment. The percentage of antagonists of the genera Gliocladium and Trichoderma (Singh et al. 2006), commonly used for biological crop protection, was much lower among all the soil-isolated fungi. These fungi belong to essential soil microbes living in the rhizosphere and in the epidermis of many plant species (Jansen and Lumsden, 1999). Members of the order Mucorales are frequently isolated from the soil. Due to their fast growth rate, intensive sporulation and the ability to use simple carbon sources, these fungi are considered antagonistic (B o e $\mathrm{r}$ et al. 2005). In the present experiment, members of the order Mucorales were isolated in relatively high numbers and showed great species diversity, which indicates their mass occurrence in the soil environment.

Large-scale experiments with the use of biological crop protection methods are often difficult to conduct since under such conditions the effects of biological control agents are unpredictable and hardly noticeable (Mathre et al. 1999). Ciccillo et al. (2002) found that the application of some inoculants containing antagonistic microorganisms caused disturbances in the microbiological equilibrium in the soil, followed by plant growth inhibition. Our field trials revealed that the applied EM inoculant modified fungal populations in the soil environment of pea. The effect of the tested pre- paration on the populations of soil fungi varied widely in particular soil zones. Kozdrój et al. (2004) demonstrated that changes taking place in the composition of rhizosphere-dwelling microbes are caused by the application of biological control agents, but are also directly related to the development stage of plants.

\section{CONCLUSIONS}

1. The application of the EM soil improver affected the population size and qualitative composition of fungi colonizing the soil environment of pea.

2. The highest population size of fungi was recorded in the experimental variant in which effective microorganisms were applied without chemical crop protection, while the lowest in the control treatment.

3. Saprotrophic fungi were most common in the rhizosphere, their percentage was lower in the rhizoplane and the lowest on the roots of pea plants.

4. The use of the EM soil improver had a slight impact on the occurrence of potentially pathogenic fungi on the roots of pea plants.

\section{REFERENCES}

Boer W., Folman L. B., Summerbell R. C., Boddy L., 2005. Living in a fungal world: impact of fungi on soil bacterial niche development. FEMS Microbiology Reviews, 29:795 811.

Ciccillo F., Fiore A., Bevivino A., Dalmastri C., Tabacchioni S., Chiarini L., 2002. Effects of two different application methods of Burkholderia ambifaria MCI 7 on plant growth and rhizospheric bacterial diver sity. Environmental Microbiology, 4: 238245.

Daly M.J., Stewart D. P. C., 1999. Influence of "effective microorganisms" (EM) on vegetative production and car bon mineralization a preliminary investigation. J. Sust. Agric. 14: 1525.

Davelos A. L., Kinkel L. L., Samac D. A., 2004. Spatial variation in frequency and intensity of antibiotic interac tions among Streptomycetes from prairie soil. Appl. Envi ron. Microbiol. 70: 10511058.

Fravel D. R., Olivain C., Alabouvette C., 2003. Fu sarium oxysporum and its biocontrol. New Phytologist. 157: 493502.

Hussain T., Javid T., Parr J.F., Jilani G., Haq M. A., 1999. Rice and wheat production in Pakistan with effec tive microorganisms. Am. J. Alt. Agric. 14: 3036.

Jensen D. F., Lumsden R. D., 1999. Biological control of soilborne pathogens. In: Albajes, R., Gullino, M. L., Van Lenteren, J. C., Elad, Y. (Eds.), Integrated Pest and Diseases Management in Greehouse Crops. Kluwer Aca demic Publishers, Dordrecht, Netherlands, pp. 319337.

Khaliq A., Kaleem Abbasi M., Hussain T., 2006. Ef fects of integrated use of organic and inorganic nutrient sources with effective microorganisms (EM) on seed cot 
ton yield in Pakistan. Bioresource Technology, 97: 967 972.

Kozdrój J., Trevors J. T., Elsas J. D., 2004. Influence of introduced potential biocontrol agents on maize seedling growth and bacterial community structure in the rhizo sphere. Soil Biology \& Biochemistry, 36: 17751784.

Mańka K., 1974. Zbiorowiska grzybów jako kryterium oceny wpływu środowiska na choroby roślin. / Fungi commu nities as a criterion of assessment of the effect of the envi ronment on plant diseases. Zasz. Prob. Post. Nauk Roln. 160: 921 .

Mathre D. E., Cook R. J., Callan N. W., 1999. From discovery to use traversing the world of commercializ ing biocontrol agents for plant disease control. Plant Dis. 83: 972983.

Morgan J. A. W., Bending G. D., White P. J., 2005. Biological costs and benefits to plant microbe interac tions in the rhizosphere. Journal of Experimental Botany, 56, (417), pp. 17291739.

Olanya O.M., Larkin R. P., 2006. Efficacy of essential oils and biopesticides on Phytophthora infestans suppression in laboratory and growth chamber studies. Biocontrol Science and Technology, 16(9): 901917.

Różański L., 1992. Przemiany pestycydów w organizmach żywych i środowisku. / Transformations of pesticides in living organisms and the environment. PWRiL Warsza wa. 268.

Seredyn Z., 1988. Badania nad grzybami zasiedlającymi środowisko owsa, łubinu i grochu uprawianych na wielo letnim ugorze. / Studies on fungi inhabiting the environ ment of oat, lupin and pea grown on long term fallow land. Pam. Puławski. 93: 145154.

Singh A., Srivastava S., Singh H. B., 2007. Effect of substrates on growth and shelf life of Trichoderma har zianum and its use in biocontrol of diseases. Bioresource Technology, 98(2):470 473.

Valarini P. J., Alvarez M. C. D., Gasco J. M., Guer rero F., Tokeshi H., 2003. Assessment of soil pro poperties by organic matter and EM microorganisms incorporation. R. Bras. Ci. Solo. 27: 519525.

\section{Grzyby zasiedlające środowisko glebowe przed siewem i po zbiorze grochu siewnego (Pisum sativum L.) po zastosowaniu szczepionki mikrobiologicznej EM $1^{\mathrm{TM}}$}

\section{Streszczenie}

Badania polowe prowadzono w latach 2003-2005. W badaniach stwierdzono wpływ szczepionki mikrobiologicznej EM 1 na zróżnicowanie składu gatunkowego i liczebność poznanych zbiorowisk grzybów. Ze środowiska glebowego w fazie kwitnienia grochu wyizolowano ogółem 18111 kolonii grzybów strzępkowych. Najliczniejsze zbiorowisko grzybów uzyskano z ryzosfery grochu kombinacji chronionej chemicznie (3257 kolonii), przy czym zbiorowiska te charakteryzowały się najmniejszą różnorodnością. Największą różnorodność gatunkową badanych zbiorowisk stwierdzono w przypadku ryzosfery i ryzoplany kombinacji, gdzie EM stosowano doglebowo w połączeniu z ochroną chemiczną. Największą różnorodność, a także liczebność grzybów wyizolowanych z korzeni roślin zanotowano w kombinacji kontrolnej. Ze środowiska glebowego grochu w fazie kwitnienia izolowano najczęściej grzyby $\mathrm{z}$ rodzaju Penicillium, które stanowiły 40,78\% izolatów grzybowych oraz z rodzaju Fusarium (32,37\%). 
